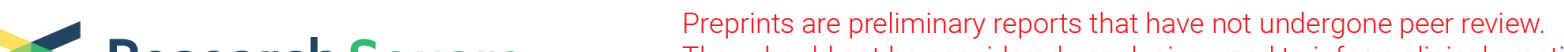 $\begin{array}{ll}\text { Research Square } & \text { They should not be considered conclusive, used to inform clinical practice, } \\ \text { or referenced by the media as validated information. }\end{array}$
}

\section{Simultaneous Removal of Soluble Metal Species and Nitrate from Acidic and Saline Industrial Wastewater in a Pilot Scale Biofilm Reactor}

\section{Panagiota Mendrinou}

National Technical University of Athens - Zografou Campus: Ethniko Metsobio Polytechneio Artin Hatzikioseyian ( $\nabla$ artin@metal.ntua.gr )

National Technical University of Athens: Ethniko Metsobio Polytechneio https://orcid.org/0000-00027638-6291

\section{Pavlina Kousi}

National Technical University of Athens - Zografou Campus: Ethniko Metsobio Polytechneio

\section{Paschalis Oustadakis}

National Technical University of Athens - Zografou Campus: Ethniko Metsobio Polytechneio

\section{Petros Tsakiridis}

National Technical University of Athens - Zografou Campus: Ethniko Metsobio Polytechneio

\section{Emmanouella Remoundaki}

National Technical University of Athens - Zografou Campus: Ethniko Metsobio Polytechneio

\section{Research Article}

Keywords: Halomonas denitrificans, metal removal, bioprecipitation, nitrate reduction, salinity, packed-bed biofilm reactor

Posted Date: May 27th, 2021

DOI: https://doi.org/10.21203/rs.3.rs-539127/v1

License: (c) (1) This work is licensed under a Creative Commons Attribution 4.0 International License. Read Full License 


\section{Abstract}

A pilot scale packed-bed biofilm reactor was set up and monitored for the treatment of wastewater originating from the hydrometallurgical recovery of metals from printed circuit boards (PCBs). The wastewater is characterized by: (a) low $\mathrm{pH}$, (b) residual soluble metal species and (c) elevated concentrations of nitrate and chloride originating from the use of nitric and hydrochloric acid as leaching agents. Such wastewater could be treated in a bioreactor capable for the simultaneous removal of metals and nitrates, through complete denitrification, in presence of elevated chloride concentrations. However, the possible inhibitory effects of metals as well as the metals bioprecipitation should be investigated experimentally. Biological denitrification was studied under extreme conditions in the bioreactor inoculated with Halomonas denitrificans: at (a) pH 3-8; (b) metal content ( $\mathrm{Cu}, \mathrm{Ni}, \mathrm{Zn}$ and $\mathrm{Fe}$ ) at $50 \mathrm{mg} / \mathrm{L}$ and $100 \mathrm{mg} / \mathrm{L}$, respectively (c) nitrate concentration 750-5,750 mg/ $\mathrm{L} \mathrm{NO}_{3}{ }^{-}$and (d) chloride concentration $5 \%-10 \%$ as $\mathrm{NaCl}$. According to the results, denitrification proceeds rapidly through the formation of nitrite as intermediate which is sequentially reduced completely to nitrogen. The presence of metals does not affect the denitrification process. Iron, zinc, copper and nickel are sequestered from the wastewater via bioprecipitation. Both goals, namely metals removal and complete reduction of nitrate in presence of elevated concentrations of chloride, were successfully achieved by the treatment scheme. The proposed simple, robust and low-cost biological treatment unit is advantageous compared to the conventional wastewater treatment, based on metal precipitation via chemical neutralization, where the problem of nitrate removal remains unresolved.

\section{Article Highlights}

- Biological denitrification at elevated soluble metals, nitrate and chloride concentrations in a biofilm reactor

- Removal of metals via bioprecipitation

- Neutralized effluent free of nitrate, nitrite and metal content

\section{Introduction}

Waste Electrical and Electronic Equipment (WEEE) ranks among the fastest growing waste streams in the world. The global generation of e-waste grew to $53.6 \mathrm{Mt}$ in 2019 with the perspective to reach $74.7 \mathrm{Mt}$ by 2030 (Forti et al. 2020). Among e-waste, printed circuit boards (PCBs) consist of 30\% of base and precious metals (copper and iron: $10 \%-20 \%$, gold, silver, platinum) as well as rare earths. Their metal content is much higher than the natural ores, making metal recovery from PCBs a worldwide priority for circular economy (Işıldar 2018). Hydrometallurgical processing can be established in local WEEE recycling industries permitting the decentralized "green" production of pure metals (Tuncuk et al. 2012; Tunsu and Retegan 2016). These processes involve essentially two steps: (a) leaching of metals, which is generally achieved by means of strong acids such as nitric, hydrochloric and their mixtures (aqua regia) and (b) separation/selective extraction of the metals of interest from the leachate. Thus, the effluents 
from the separation and recovery stages contain residual anions such as $\mathrm{NO}_{3}{ }^{-}, \mathrm{Cl}^{-}$as well as residual metal ions which have not been recovered. Neutralization of these streams resolves the problem of acidity, removes part of the soluble metal ions as hydroxides when $\mathrm{Ca}(\mathrm{OH})_{2}$ is used as neutralizing agent. However, the concentration of nitrate and chloride does not alter significantly as these anions remain mobile.

Soluble nitrogen compounds, i.e., nitrate or nitrite, can cause serious environmental and human health problems when discharged untreated in water bodies. The established discharge limit for nitrate in drinking water is $50 \mathrm{mg} / \mathrm{L} \mathrm{NO}_{3}{ }^{-}$(or $11 \mathrm{mg} / \mathrm{L} \mathrm{NO}_{3}-\mathrm{N}$ ) and for nitrite $5 \mathrm{mg} / \mathrm{L} \mathrm{NO}_{2}{ }^{-}$(WHO, 2017). Removal of chloride, nitrate and sulfate with conventional treatment options, such as reverse osmosis and ion exchange, is costly. Biological denitrification is a promising, cost effective alternative process which has proven efficiency and selectivity (Matějü et al. 1992). The biological action is stepwise and is completed via four enzymatic steps (reactions (1)-(4)) which are catalyzed by specific enzymes; molybdenum containing nitrate reductase, cytochrome $c d 1$ or copper containing enzymes, nitric oxide reductase and nitrous oxide reductase, respectively (Tavares et al. 2006).

$$
\begin{aligned}
& \mathrm{NO}_{3}^{-}+2 \mathrm{e}^{-}+2 \mathrm{H}^{+} \rightarrow \mathrm{NO}_{2}^{-}+\mathrm{H}_{2} \mathrm{O} \\
& \mathrm{NO}_{2}^{-}+\mathrm{e}^{-}+2 \mathrm{H}^{+} \rightarrow \mathrm{NO}+\mathrm{H}_{2} \mathrm{O} \\
& 2 \mathrm{NO}+2 \mathrm{e}^{-}+2 \mathrm{H}^{+} \rightarrow \mathrm{N}_{2} \mathrm{O}+\mathrm{H}_{2} \mathrm{O} \\
& \mathrm{N}_{2} \mathrm{O}+2 \mathrm{e}^{-}+2 \mathrm{H}^{+} \rightarrow \mathrm{N}_{2}+\mathrm{H}_{2} \mathrm{O}
\end{aligned}
$$

The overall denitrification reaction can be expressed as a single redox reaction (5):

$$
2 \mathrm{NO}_{3}^{-}+10 \mathrm{e}^{-}+12 \mathrm{H}^{+} \rightarrow \mathrm{N}_{2}+6 \mathrm{H}_{2} \mathrm{O}
$$

Heterotrophic denitrification has been demonstrated feasible and efficient for the treatment of industrial wastewater which is characterized by elevated nitrate concentrations and no or low metal content. For example, Fernández-Nava et al. 2008 report that the biological reduction of nitrate in the presence of calcium from rinse wastewater generated in stainless steel manufacturing process is feasible by achieving $98 \%$ nitrate removal in $7 \mathrm{~h}$ although they observed that increased calcium concentrations have negative effect of on denitrification rate (Fernández-Nava et al. 2008). Similarly, successful biological reduction of nitrate has been reported for a metal-finishing industry (Gabaldón et al. 2007), simulated mine and mill effluents (Koren et al. 2000) and mine waters (Mattila et al. 2007). Since industrial wastewater contains little or no organic carbon, a suitable carbon source and electron donor must be supplied with the wastewater to achieve biological denitrification. In industrial practice methanol is mainly used as carbon source (Gabaldón et al. 2007; Koren et al. 2000). 
Metals have been reported to inhibit denitrifiers in soil, sediments and activated sludge (Baeseman et al. 2006; Magalhães et al. 2007; Sakadevan et al. 1999; Ochoa-Herrera et al. 2011). It has also been experimentally demonstrated via batch assays that the denitrifying activity is affected in the case of synthetic mineral solutions containing Fe (Ramírez et al. 2018; Papirio et al. 2014), Ni (Ramírez et al. 2018; Zou et al. 2014), Co (Zou et al. 2014) and Cr (Ramírez et al. 2018), causing accumulation of undesirable intermediates, such as $\mathrm{NO}_{2}{ }^{-}$and $\mathrm{N}_{2} \mathrm{O}$ (Ramírez et al., 2018). Special attention has been given to the effect of copper (Woolfenden et al. 2013; Felgate et al. 2012; Papirio et al. 2014; Zhao et al. 2020; Cheng et al. 2019), due to the copper-containing enzyme regulating the reduction of nitrous oxide into nitrogen. Therefore, the microbially-mediated denitrification in the presence of elevated metal concentrations remains challenging (Hirata et al. 2001; Zou et al. 2015).

Moreover, when also the removal of metals is the main goal, as in the case of industrial wastewater treatment, the biological activity should not be inhibited in order to simultaneously achieve denitrification and metals bioprecipitation. The later occurs as a result of the alkalinity produced through the biological activity. Insoluble metal hydroxides and carbonates can be precipitated as the $\mathrm{pH}$ is shifted to more alkaline values and carbonates are produced from the oxidation of organic carbon. When sulfates are also fed in the reactor and the conditions are appropriate, metal sulfides exhibiting lower solubilities over a wider $\mathrm{pH}$ range, may also form. These processes, collectively termed as bioprecipitation, are well documented in the biomineralization literature (Remoudaki et al. 2003; Tsezos et al. 2007; Kousi et al. 2011).

In this work a pilot scale packed bed biofilm reactor was set-up with a novel type porous packing material which embeds trace elements aiming to support the micronutrient requirements of an active biofilm. The bioreactor was inoculated with Halomonas dentrificans, a halophilic denitrifier, capable of completely reducing nitrate to elemental nitrogen in the presence of high chloride, high nitrate and metal ion content.

The purpose of this study is to experimentally investigate and demonstrate the feasibility of the biological denitrification at elevated nitrate $\left(\approx 6 \mathrm{~g} / \mathrm{L} \mathrm{NO}_{3}{ }^{-}\right)$and chloride $(10 \% \mathrm{w} / \mathrm{v} \mathrm{NaCl})$ concentrations in the presence of $100 \mathrm{mg} / \mathrm{L} \mathrm{Zn,} \mathrm{Cu,} \mathrm{Fe}$ and $\mathrm{Ni}$, respectively to meet three goals in a single stage treatment process (a) wastewater neutralization (b) nitrate removal and (c) soluble metal species precipitation. To the best of our knowledge such combined results have not been reported in the literature for waste streams originating from the hydrometallurgical treatment of WEEE where nitric/hydrochloric acid and/or aqua regia are commonly used as leaching agents.

\section{Materials And Methods}

\subsection{Bioreactor set-up}

A pilot scale packed-bed reactor was selected as the bioreactor configuration for the treatment of wastewater containing nitrate and metal ions. The schematic of the reactor is shown in Fig. 1(a) while the picture of the unit is presented in Fig. S1 (Supplementary material). Such a bioreactor set-up has been 
previously tested and found highly efficient for the treatment of acidic, sulphate- and metal-bearing wastewater (Kousi et al. 2007, Kousi et al. 2011). The reactor was made from transparent PVC, $50 \mathrm{~cm}$ in length and $9.5 \mathrm{~cm}$ in internal diameter. Two types of packing biofilm support material were used: (a) spherical porous sintered-glass beads of average diameter 2.7-3.0 cm (Biohome Supergravel, Fig. 1(b)) filling the lowest $5 \mathrm{~cm}$ of the column and (b) cylindrical porous sintered-glass pieces of average length 2.8-3.5 cm and average diameter $1 \mathrm{~cm}$ (Biohome Ultimate Marine, Fig. 1(c)) filling the rest $40 \mathrm{~cm}$ of the column. At the top of the column, a headspace of $5 \mathrm{~cm}$ was provided for safety facilitating the release of any gaseous products.

The packing material was produced and provided by Aqua Bio UK Ltd (https://filterpro.co.uk/). It was selected due to its durability, the low pressure drop, the high porosity (approximately $50 \%$ according to the technical data sheet of the supplier), the good wetting properties and the trace elements content which facilitates the development of active biofilm by providing the required trace elements for microbial growth (mainly Fe and $\mathrm{Mn}$ ). The microscopic structure of the packing material is shown in the scanning electron microscope (SEM) images Fig. 1(d) for Biohome Supergravel and Fig. 1(e) for Biohome Ultimate. The related Energy Dispersive Spectra (EDS) at selected sites show characteristic peaks of silicon (Si) and oxygen ( 0 ) confirming that both Biohome Supergravel (Fig. 1(f)) and Biohome Ultimate (Fig. 1(g)) consist mainly of sintered glass. Both materials are also enriched by proprietary methods with trace elements, such as aluminum (Al), iron (Fe), manganese $(\mathrm{Mn})$, chromium ( $\mathrm{Cr}$ ), sodium $(\mathrm{Na})$, bromine $(\mathrm{Br})$, calcium (Ca), titanium ( $\mathrm{Ti})$ and magnesium $(\mathrm{Mg})$.

All experiments have been carried out in the bioreactor running in upflow mode in sequencing batch operation. This means that the column outflow was fully returned into a well-mixed continuous stirred tank reactor (CSTR) from where it was fed again by means of a peristaltic pump (Shenchen LabM6). The liquid volume retained in the bioreactor was $1.7 \mathrm{~L}$, corresponding to $53 \%$ void space of the packing material. The working volume of the CSTR was $1 \mathrm{~L}$. Thus, in each batch, a total volume of $2.7 \mathrm{~L}$ of wastewater was treated.

\section{2 icrobial culture - growth medium}

The bioreactor was inoculated with a pure culture of the strain Halomonas denitrificans (DSM-18045), which was received from the Deutsche Sammlung von Mikroorganismen und Zellkulturen (DSMZ, Germany), in pre-grown liquid culture in Bacto Marine Broth medium (DSMZ medium $514+8 \% \mathrm{NaCl}$ ) containing (in g/L): Bacto peptone, 5, yeast extract, 1, $\mathrm{Fe}^{3+}$ citrate, $0.10, \mathrm{MgCl}_{2} .6 \mathrm{H}_{2} \mathrm{O}, 12.61, \mathrm{Na}_{2} \mathrm{SO}_{4}, 3.24$, $\mathrm{CaCl}_{2} .2 \mathrm{H}_{2} \mathrm{O}, 2.66, \mathrm{KCl}, 0.55, \mathrm{NaHCO}_{3}, 0.16, \mathrm{KBr}, 0.08, \mathrm{H}_{3} \mathrm{BO}_{3}, 0.022, \mathrm{NH}_{4} \mathrm{NO}_{3}, 0.0016, \mathrm{Na}_{2} \mathrm{HPO}_{4}, 0.008$.

Halomonas denitrificans was first isolated from saline water in Anmyeondo, Korea (Kim et al. 2007). The strain was selected for our experiments due to two specific characteristics: (a) its halotolerant nature which allows its growth in environments of high salinity, i.e., high chloride content (Miao et al. 2015) and (b) its phylogenetic traits which denote its ability to reduce completely nitrate to nitrogen gas (González- 
Domenech et al. 2010, Felgate et al. 2012). There are no reports that the strain can tolerate elevated concentrations of metal ions which is tested for the first time in this work.

\subsection{Bioreactor start-up}

Before inoculation, the reactor body, the packing material and the silicon tubing were sterilized by recirculating $70 \%$ ethanol for $3 \mathrm{~h}$ followed by thorough rinsing with $3 \mathrm{~L}$ sterile deionized water. Bacto Marine Broth supplemented with $10 \% \mathrm{~W} / \mathrm{v} \mathrm{NaCl}$ and $1,000 \mathrm{mg} / \mathrm{L} \mathrm{NO}_{3}{ }^{-}$was used as growth medium for culture growth and transfer. An inoculum of $3 \mathrm{~L}$ was used for the first and subsequent inoculations of the reactor. The inoculation process was repeated 4 times: each phase lasted 5 days during which the reactor was run in sequencing batch mode for establishing an active biofilm on the surface and the pores of the packing material. The reactor was self-running with fresh medium (without microorganisms) after 21 days from the initial inoculation, indicating that an active biofilm was already established in the reactor. Subsequent experiments were performed in non-sterile clean conditions, while the reactor was periodically (on average, monthly) re-inoculated to ensure the dominance of Halomonas denitrificans in the biofilm.

\subsection{Experimental set-up}

In order to investigate the denitrification capacity and the metal tolerance and removal under high chloride concentration different operating conditions have been tested in the bioreactor. Four groups of experiments were designed and are reported in this work. All experiments have been carried out in duplicate and in ambient temperature.

a. In order to examine the tolerance and the denitrification capability of the microbial culture three different levels of initial nitrate concentrations were tested: $750 \mathrm{mg} / \mathrm{L}, 2,750 \mathrm{mg} / \mathrm{L}$ and 5,750 mg/L $\mathrm{NO}_{3}{ }^{-}$. The ability of the microbial culture to tolerate and respire only on nitrite was also examined at initial concentration $2,000 \mathrm{mg} / \mathrm{L} \mathrm{NO}_{2}^{-}$.

b. The effect of $\mathrm{pH}$ on the denitrification process was investigated at initial $\mathrm{pH} 3,4,5,6$ and 8 at initial $\mathrm{NO}_{3}{ }^{-}$concentration $1,250 \mathrm{mg} / \mathrm{L} \mathrm{NO}_{3}$. The initial $\mathrm{pH}$ of the medium was adjusted by the addition of $0.1 \mathrm{~N} \mathrm{HCl}$ or $0.1 \mathrm{~N} \mathrm{NaOH}$ as appropriate.

c. The effect of salinity on the denitrification process was studied at $\mathrm{pH} 3$ by adjusting the concentration of $\mathrm{NaCl}$ to $10 \% \mathrm{~W} / \mathrm{v}\left(\right.$ at $\left.1,250 \mathrm{mg} / \mathrm{L} \mathrm{NO}_{3}{ }^{-}\right), 7.5 \% \mathrm{w} / \mathrm{v}\left(\right.$ at $2,750 \mathrm{mg} / \mathrm{L} \mathrm{NO}_{3}{ }^{-}$) and $5 \% \mathrm{~W} / \mathrm{v}$ (at $3,250 \mathrm{mg} / \mathrm{L} \mathrm{NO}_{3}{ }^{-}$).

d. To examine the effect of metal ions on the denitrification process as well as the fate of the metals during denitrification, a set of experiments was carried out at $\mathrm{pH} 3$, nitrate concentration 2,750$3,250 \mathrm{mg} / \mathrm{L} \mathrm{NO}_{3}{ }^{-}$and $5 \% \mathrm{~W} / \mathrm{v} \mathrm{NaCl}$ at two different initial metal concentrations: $50 \mathrm{mg} / \mathrm{L}$ and $100 \mathrm{mg} / \mathrm{L}$. Four divalent metal ions were added separately (acclimation period 4 days before sampling): $\mathrm{Fe}^{2+}$ was added as $\mathrm{FeSO}_{4} \cdot 7 \mathrm{H}_{2} \mathrm{O}, \mathrm{Cu}^{2+}$ was added as $\mathrm{CuCl}_{2} \cdot 2 \mathrm{H}_{2} \mathrm{O}, \mathrm{Ni}^{2+}$ was added as $\mathrm{NiCl}_{2} \cdot 6 \mathrm{H}_{2} \mathrm{O}$ and $\mathrm{Zn}^{2+}$ was added as $\mathrm{ZnCl}_{2}$. Abiotic experiments were also carried out for studying 
nickel precipitation at $50 \mathrm{mg} / \mathrm{L} \mathrm{Ni}^{2+}$ by sweeping $\mathrm{pH}$ values from 3 to 8 in aqueous solutions in the presence of peptones with and without yeast extract.

\subsection{Sampling and monitoring of the reactor}

Samples were collected hourly from the reactor outflow (stream returned to the CSTR compartment) for the first 6 hours and once at 24 hours for each run as appropriate. $\mathrm{pH}$ was determined on unfiltered samples. For all subsequent analytical determinations, the samples were vacuum filtered through $0.20 \mu \mathrm{m}$ sterile membrane filters (Whatman ME 24/21 ST). The concentration of nitrate and nitrite were determined colorimetrically according to: Merck method 1.09713.0001 for nitrate adjusted to Hach DR/2500 at $340 \mathrm{~nm}$ and Merck method 1.14776.0002 for nitrite adjusted to Hach DR/2500 at $550 \mathrm{~nm}$, respectively. The measuring range for nitrate and nitrite were $0-20 \mathrm{mg} / \mathrm{L} \mathrm{NO}_{3}-\mathrm{N}$ and 0.02-1 mg/ $\mathrm{L} \mathrm{NO}_{2}-\mathrm{N}$, respectively. Total organic carbon (TOC) was determined by colorimetry (Hach method 10129, DR/2500) with measuring range $0-20 \mathrm{mg} / \mathrm{L} \mathrm{TOC}$. The method is based on the oxidation of the organic carbon to carbon dioxide by persulphate and subsequent photometric measurement of the color change of a pH indicator. The concentrations of soluble copper, nickel, iron and zinc were determined by flame atomic absorption spectroscopy (AAS) after acidification of the samples by $\mathrm{HNO}_{3}$.

The microstructural investigation of the bioreactor residue was carried out by scanning electron microscopy (SEM) using a Jeol 6380 LV microscope. Experimental conditions involved $15 \mathrm{kV}$ accelerating voltage at low vacuum (30 Pa), using a backscattered electron detector. Microanalysis was performed by an Oxford INCA Energy Dispersive Spectrometer (EDS) connected to the SEM. SEM was performed in polished sections, which had been produced by vacuum impregnation, of the selected sample, in a low viscosity epoxy resin. After removing a small surface by cutting in micro-saw, the sample was grinded and polished with $1 \mu \mathrm{m}$ diamond paste, on a lapping disk.

\section{Results And Discussion}

\subsection{Kinetics of nitrate and nitrite reduction}

The kinetics of nitrate reduction was studied at initial concentration $750 \mathrm{mg} / \mathrm{L}, 2,750 \mathrm{mg} / \mathrm{L}$ and $5,750 \mathrm{mg} / \mathrm{L} \mathrm{NO}_{3}{ }^{-}$(Fig. 2(a)). Increased initial nitrate concentration requires higher times for complete denitrification. However, complete nitrate removal is attained within $4 \mathrm{~h}$ and $6 \mathrm{~h}$ for the case of $750 \mathrm{mg} / \mathrm{L}$, $2,750 \mathrm{mg} / \mathrm{L} \mathrm{NO}_{3}{ }^{-}$, respectively, whereas at $5,750 \mathrm{mg} / \mathrm{L} \mathrm{NO}_{3}{ }^{-}$, complete denitrification is observed within 25 hours. In parallel, monitoring of the nitrite concentration verifies that nitrate is reduced via the formation of nitrite as intermediate. Nitrite concentration profiles (Fig. 2(b)) correspond to typical kinetic curves of an intermediate produced and sequentially consumed in a sequence of reactions in series. Thus, the peaks in the curves of Fig. 2(b) correspond to the time when nitrite reduction rate is higher than nitrite production rate. The same profiles also show that the maximum nitrite concentration depends on the initial nitrate concentration: profiles peaks at $200 \mathrm{mg} / \mathrm{L}, 580 \mathrm{mg} / \mathrm{L}$ and 1,000 mg/ $/ \mathrm{L} \mathrm{NO}_{2}{ }^{-}$are observed for $750 \mathrm{mg} / \mathrm{L}, 2,750 \mathrm{mg} / \mathrm{L}$ and $5,750 \mathrm{mg} / \mathrm{L} \mathrm{NO}_{3}{ }^{-}$, at $2 \mathrm{~h}, 4 \mathrm{~h}$ and $5 \mathrm{~h}$, respectively. Complete nitrite reduction is 
observed within $4 \mathrm{~h}$ for the case of $750 \mathrm{mg} / \mathrm{L} \mathrm{NO}_{3}{ }^{-}$and less than $25 \mathrm{~h}$ for the cases of 2,750 mg/ $\mathrm{L}$ and $5,750 \mathrm{mg} / \mathrm{L} \mathrm{NO}_{3}{ }^{-}$. In summary, all soluble forms of nitrogen species (i.e., $\mathrm{NO}_{3}{ }^{-}$and $\mathrm{NO}_{2}{ }^{-}$) were completely removed from the wastewater within $25 \mathrm{~h}$ even at the highest initial nitrate concentrations tested (i.e., $5,750 \mathrm{mg} / \mathrm{L} \mathrm{NO}_{3}{ }^{-}$). The results confirm the high denitrification capacity of the biofilm reactor achieved by the strain Halomonas denitrificans.

The evolution profile of $\mathrm{pH}$ vs. time (Fig. 2(c)) verifies the shift of $\mathrm{pH}$ towards more alkaline values as the reduction of nitrate to nitrogen proceeds via the consumption of protons (reaction). The rise of $\mathrm{pH}$ depends on the extent of nitrate reduction: higher initial nitrate concentrations correspond to higher final $\mathrm{pH}$ values. $\mathrm{pH}$ profiles show also a consistent pattern: initial $\mathrm{pH}(6.2-7.2)$ raises steeply to reach a peak value from where it keeps slowly decreasing up to an equilibrium value. The peak values $7.6,8.3$ and 8.6 for an initial concentration of $750 \mathrm{mg} / \mathrm{L}, 2,750 \mathrm{mg} / \mathrm{L}$ and $5,750 \mathrm{mg} / \mathrm{L} \mathrm{NO}_{3}{ }^{-}$, respectively coincide with zero residual nitrate concentration.

The ability of Halomonas denitrificans to grow only by reducing nitrite in the absence of nitrate was investigated by initiating an experiment with initial concentration of $2000 \mathrm{mg} / \mathrm{L} \mathrm{NO}_{2}{ }^{-}$as the sole electron acceptor. The results shown in Fig. 2(a) proves that there is no apparent delay of nitrite reduction which is completely reduced within 6 hours to elemental nitrogen. Therefore, it is confirmed that the strain Halomonas denitrificans can grow in the absence of nitrate by using only nitrite as terminal electron acceptor (nitrite respiration). This is in alignment with the observations that nitrite as intermediate of nitrate reduction is also consumed. It should be noted that the $\mathrm{pH}$ of the effluent when only nitrite was present reached a peak of 8.8 while maintaining the highest observed equilibrium pH value of 8.3 (Fig. 2(c)). Complete reduction of nitrate to the harmless elemental nitrogen is a significant prerequisite to successful treatment of any nitrate containing wastewater. Residual concentrations of nitrite are undesirable after wastewater treatment. However, it should be noted that not all the microbial species can carry out complete denitrification. Many species stop the reduction process to some intermediates such as nitrite, nitic oxide $(\mathrm{NO})$ or nitrous oxide $\left(\mathrm{N}_{2} \mathrm{O}\right)$ or starts the reduction process from these intermediates (Kim et al. 2007, Holmes et al. 2019, You et al. 2020).

The results from the monitoring of TOC (figure not shown) indicates that about $87 \%$ of TOC originates from the bacto peptone source while the rest $13 \%$ from the yeast extract contained in the growth medium. TOC degradation reached about $50 \%$ in all runs representing the conversion of the organic fraction of peptones and yeast into $\mathrm{CO}_{2}$. Under these conditions, it was ensured that the substrate source was never in growth limiting conditions and did not limit the denitrification process.

\subsection{The effect of initial pH on denitrification}

The effect of the initial pH on the denitrification process has been studied at $\mathrm{pH} 3,4,5,6$ and 8 (Fig. $3(\mathrm{a})-3(\mathrm{f}))$ versus the non-adjusted $\mathrm{pH}$ of the feed solution $(\mathrm{pH}=6.8)$. Although the scope of this study is the treatment of acidic wastewater, the effect of $\mathrm{pH}$ over wider $\mathrm{pH}$ range was investigated. All 
experiments have been carried out with nitrate as electron acceptor at $1,250 \mathrm{mg} / \mathrm{L} \mathrm{NO}_{3}{ }^{-}$. In these experiments it is also confirmed that denitrification proceeds through the formation of nitrite and the subsequent reduction of nitrite to nitrogen (Fig. 3(a)-(d)). However, the initial pH of the medium affects significantly the concentration of nitrite (Fig. 3(c)-(d)). Both nitrate and nitrite are reduced within $4 \mathrm{~h}$ for acidic initial $\mathrm{pH}$. For $\mathrm{pH} 3,4$ and 5 , the maximum nitrite concentration is lower than $75 \mathrm{mg} / \mathrm{L}$, while for the circum-neutral and alkaline initial $\mathrm{pH}$ values, i.e., 6, 6.8 and 8, nitrite concentration is significantly higher $(120 \mathrm{mg} / \mathrm{L}-200 \mathrm{mg} / \mathrm{L}$ ) and complete reduction is observed at $24 \mathrm{~h}$. Therefore, it can be concluded that under acidic $\mathrm{pH}$ lower nitrite maxima are observed that can be attributed either to the increased rate of nitrite reduction and/or to the decreased rate of nitrate reduction. This result is on the benefit of the proposed process as the aim of the treatment unit is to treat highly acidic streams with short treatment time concerning nitrate reduction and lower peak nitrite concentrations as temporary intermediate byproduct.

The control experiment at $\mathrm{pH} 6.8$ showed a typical profile with a peak of 8 and a tail reaching equilibrium at $\mathrm{pH}$ 7.8. When the initial $\mathrm{pH}$ of the feed solution was adjusted to 3,4 and $5, \mathrm{pH}$ increased considerably to an equilibrium value of around 7.5 (Fig. 3(e)). When the initial $\mathrm{pH}$ was adjusted to 6 and 8 , the corresponding equilibrium $\mathrm{pH}$ was 7.3 and 7.8, respectively (Fig. 3(f)). The steep increase of $\mathrm{pH}$, especially in the case of acidic values (i.e., 3, 4 and 5), demonstrates the efficiency of the treatment unit to tolerate and neutralize acidic wastewater originating from WEEE acid leaching processes. It has been experimentally shown that biofilm reactors tolerate feed $\mathrm{pH}$ as low as 2.5 with no adverse effects on denitrification (Papirio et al. 2014). In our work also, the established biofilm tolerates acidic feeds $(\mathrm{pH}=3$ ) and achieves both aims, namely wastewater neutralization and soluble nitrogen removal, within $4 \mathrm{~h}$ (Fig. $3(\mathrm{a})$-(d)). Furthermore, the inherent increase of $\mathrm{pH}$ during denitrification process to $\mathrm{pH}$ 7.5-8.0 also affects the solubility and mobility of the metal ions of the medium as will be discussed following.

\subsection{The effect of salinity on denitrification}

The effect of salinity on the denitrification process was studied at three different chloride levels ( $\mathrm{NaCl}: 5 \%$ $\mathrm{w} / \mathrm{v}, 7.5 \% \mathrm{w} / \mathrm{v}$ and $10 \% \mathrm{w} / \mathrm{v})$. These experiments simulate the presence of chloride in the wastewater by the use of aqua regia as leaching solution as well as the high ionic strength anticipated in the wastewater due to dissolved species (i.e., nitrate, chloride and metal ions). The results proved that the increased salinity does not affect the denitrification process which is completed within 4 hours even started from different nitrate initial concentrations (Fig. 4(a)). However, Fig. 4(b) shows that salinity affects the temporal accumulation of nitrite in the medium implementing that it has a direct effect on the physiology

of denitrification of Halomonas denitrificans. Similar findings have been confirmed in the literature for the genus of Halomonas (Miao et al. 2015). The pH profiles as shown in Fig. 4(c), stating from pH 3 in all cases, increases steeply within $2 \mathrm{~h}$ close to neutral values $(\mathrm{pH} \approx 7.0-7.7)$ regardless of the salinity levels.

\subsection{The effects of $\mathrm{Zn}, \mathrm{Cu}, \mathrm{Fe}$ and $\mathrm{Ni}$ on denitrification}


The effect of zinc, copper, iron and nickel on the denitrification process was studied for each metal individually for two initial metal concentrations, $50 \mathrm{mg} / \mathrm{L}$ and $100 \mathrm{mg} / \mathrm{L}$, respectively. The effect of the same metals in a mixture of $20 \mathrm{mg} / \mathrm{L}$ or $50 \mathrm{mg} / \mathrm{L}$ from each one has also been studied (Supplementary material, section S2, Fig. S2.1).

Fig. 5(a)-5(f) presents the concentration profiles of nitrate, nitrite and profiles of $\mathrm{pH}$ vs. time compared to the control experiment without any metal addition in the wastewater. Complete reduction of nitrate is systematically observed within 5 hours for the four metals tested in both concentrations (Fig. 5(a)-(b)) indicating that there is not noticeable inhibition on the denitrification process due to the presence of the metal ions. However, the effect of the metals on the denitrification physiology of Halomonas denitrificans can be clustered in two groups: (a) zinc and copper and (b) iron and nickel, indicating similar behavior. Figures 5(a)-5(b) present that denitrification in the presence of $\mathrm{Zn}$ and $\mathrm{Cu}$ is completed within 3 hours while in the case of Fe and $\mathrm{Ni}$, denitrification is completed in 5 hours at $50 \mathrm{mg} / \mathrm{L}$ or $100 \mathrm{mg} / \mathrm{L}$ initial metal concentration. The effects of these metals are more noticeable in the concentration profiles of nitrite (Fig. $5(\mathrm{c})-5(\mathrm{~d}))$. In the cases of Fe and Ni, nitrite concentration is extremely low at both $50 \mathrm{mg} / \mathrm{L}$ and $100 \mathrm{mg} / \mathrm{L}$ in contrast with the cases of $\mathrm{Zn}$ and $\mathrm{Cu}$. Particularly for the cases of $\mathrm{Zn}$ and $\mathrm{Cu}$, peek concentrations of $75 \mathrm{mg} / \mathrm{L}$ and 100-150 mg/L NO${ }_{2}^{-}$have been observed (Fig. 5(c)-5(d)) for $50 \mathrm{mg} / \mathrm{L}$ and $100 \mathrm{mg} / \mathrm{L}$ metal concentration, respectively. These indicate that $\mathrm{Ni}$ and Fe affect significantly the enzymatic activity of nitrite reduction by decelerating the rate of nitrate reduction and accelerating the rate of nitrite reduction. The opposite behavior is observed in the cases of $\mathrm{Zn}$ and $\mathrm{Cu}$ where nitrate reduction rates are high but nitrite reduction rates are low.

Concerning the evolution of $\mathrm{pH}(\mathrm{Fig} .5(\mathrm{e})-5(\mathrm{f}))$ for all metals and at both concentrations, starting form $\mathrm{pH}$ 3 , pH shifts within 2 hours to 7.2-7.5 and equilibrates at a value close to 8.0.

\subsection{The fate of $\mathrm{Zn}, \mathrm{Cu}, \mathrm{Fe}$ and Ni during denitrification}

The concentration profiles of soluble $\mathrm{Zn}, \mathrm{Cu}, \mathrm{Fe}$ and $\mathrm{Ni}$ during denitrification at $50 \mathrm{mg} / \mathrm{L}$ and $100 \mathrm{mg} / \mathrm{L}$ initial concentrations are presented in Fig. 6(a)-6(d), respectively. Soluble metals fed in the reactor either separately (Fig. 6(a)-6(d)) or as a mixture of the four metals (Supplementary material, Fig. S2.2) were sequestered from the solution within 6 hours except nickel. Nickel exhibits an S-shaped kinetic profile different from the other three metals (Fig. 6(d)).

As it has been shown in Figs. 2(c), 3(e), 3(f), 4(c), 5(e) and 5(f), the pH of the wastewater is always shifted to $\mathrm{pH}$ around 7.5-8.0 within 2 hours due to the complete reduction of the negatively charged nitrate/nitrite ions from the medium to the neutral elemental nitrogen. Under these conditions, the excess of hydroxyl ions can react with the soluble metal species and form the corresponding metal hydroxide precipitates during the progressive shift of the $\mathrm{pH}$ to more alkaline values (Fig. S3(a) and Fig. S3(b)). The formation of metal carbonates via bicarbonate ions $\left(\mathrm{HCO}_{3}{ }^{-}\right)$from the oxidation of the carbon source of the peptones and yeast extract is also possible. In addition, when biological sulfate reduction is favored, the 
formation of metal sulfide is also possible and dominates the bioprecipitation mechanism due to the lower solubility of sulfides compared to metal hydroxides and carbonates (Fig. S3(c)) (Lewis 2010).

To explain the precipitation pattern of $\mathrm{Ni}$ (Fig. 6(d)), a set of experiments were carried out to elucidate the role of organic moieties in forming stable complexes with nickel ions. Solubility curves were experimentally determined for the cases of: (a) a solution of $50 \mathrm{mg} / \mathrm{L} \mathrm{Ni}^{2+}$, (b) same as (a) supplemented with $2.5 \mathrm{~g} / \mathrm{L}$ peptone, (c) same as (a) supplemented with $5.0 \mathrm{~g} / \mathrm{L}$ peptone and (d) same as (a) supplemented with $5.0 \mathrm{~g} / \mathrm{L}$ peptone and $1 \mathrm{~g} / \mathrm{L}$ yeast extract (Fig. S4). In the same figure the simulated solubility curve for nickel is presented as calculated from the speciation software Visual Minteq ver. 3.1 (https://vminteq.Iwr.kth.se/). The results revealed that when the organic content of nickel solutions is high, as are the conditions that prevail in the fresh batches $(5.0 \mathrm{~g} / \mathrm{L}$ peptones with $1.0 \mathrm{~g} / \mathrm{L}$ yeast extract) or even at $5.0 \mathrm{~g} / \mathrm{L}$ and $2.5 \mathrm{~g} / \mathrm{L}$ peptones alone in the solution, nickel remain soluble and does not form insoluble nickel hydroxides over the range of $\mathrm{pH}$ from 3 to 8 due to the formation of metal-organic complexes. Similar behavior, which affects the solubility of the metal ions, has been observed also for the case of chromium, where the effect of various organic moieties on the solubility of the metal has been studied systematically (Remoundaki et al. 2003, Remoundaki et al. 2007). Therefore, the S-shaped kinetic profile of nickel and the slow sequestering at the first 5 hours is attributed to the soluble complexes formed with the organic content of the medium. As the degradation of the substrate proceeds, these complexes are dissociated permitting the formation of insoluble nickel species.

\section{Conclusions}

This work presents an effective biological process for the simultaneous removal of metals and nitrate from acidic, highly saline wastewater. The process is robust and capable of treating metal-bearing wastewater at $\mathrm{pH}$ values as low as 3 , nitrate at concentration as high as $5,750 \mathrm{mg} / \mathrm{L} \mathrm{NO}_{3}{ }^{-}$and tolerate salinity as high as $10 \%$ as $\mathrm{NaCl}$. The experimental results demonstrated that the reactor may operate over a wide range of values of the above parameters, maintaining a high efficiency. It is anticipated that even more extreme conditions in terms of lower $\mathrm{pH}$, higher $\mathrm{NO}_{3}{ }^{-}$and higher metal content could be tackled successfully which is the aim of the ongoing research activity. This work demonstrates in pilot scale that the aims to neutralize the waste stream, completely remove nitrate without residual forms of reduced nitrogen and precipitate the metal content of the solution (i.e., Zn, Cu, Fe and $\mathrm{Ni}$ each at $100 \mathrm{mg} / \mathrm{L}$ ) via bioprecipitation were achieved in one stage with the proposed biological system. The process can be applied as a main treatment option or polishing stage in any industrial case where such complex and hazardous wastewater needs to be treated with minimal treatment cost before being safely discharged to the environment.

\section{Declarations}

\section{Acknowledgments - Funding}


This research has been co-financed by the European Regional Development Fund of the European Union and Greek national funds through the Operational Program Competitiveness, Entrepreneurship and Innovation, under the call RESEARCH - CREATE - INNOVATE (project code: T1EDK-00219).

\section{Data Availability}

All data are available by the authors upon request.

\section{Compliance with Ethical Standards}

All the ethical standards were followed.

\section{Conflict of Interest Statement}

The authors declare no conflict of interest

\section{Authors' contribution}

Artin Hatzikioseyian, Pavlina Kousi and Emmanouella Remoundaki contributed to the study conception and design. Material preparation, data collection and analysis were performed by Panagiota Mendrinou, Paschalis Oustadakis and Petros Tsakiridis. All authors contributed equally to the interpretation of the results and provided critical feedback. The first draft of the manuscript was written by Panagiota Mendrinou and revised by all authors who read and approved the final manuscript.

\section{References}

1. Baeseman JL, Smith RL, Silverstein J (2006) Denitrification potential in stream sediments impacted by acid mine drainage: effects of pH, various electron donors and iron. Microb Ecol 51 (2):232-241. https://doi.org/10.1007/s00248-005-5155-z

2. Cheng YF, Zhang Q, Li GF, Xue Y, Zheng XP, Cai S, Zhang ZZ, Jin RC (2019) Long-term effects of copper nanoparticles on granule-based denitrification systems: Performance, microbial communities, functional genes and sludge properties. Bioresour Technol 289:121707. https://doi.org/10.1016/j.biortech.2019.121707

3. Felgate H, Giannopoulos G, Sullivan MJ, Gates AJ, Clarke TA, Baggs E, Rowley G, Richardson DJ (2012) The impact of copper, nitrate and carbon status on the emission of nitrous oxide by two species of bacteria with biochemically distinct denitrification pathways. Environ Microbiol 14 (7):1788-1800. 10.1111/j.1462-2920.2012.02789.x

4. Fernández-Nava Y, Marañón E, Soons J, Castrillón L (2008) Denitrification of wastewater containing high nitrate and calcium concentrations. Bioresour Technol 99 (17):7976-7981. http://doi.org/10.1016/j.biortech.2008.03.048

5. Forti V, Baldé CP, Kuehr R, Bel G (2020) The global e-waste monitor 2020: quantities, flows and the circular economy potential. United Nations University (UNU)/United Nations Institute for Training and 
Research (UNITAR) - co-hosted SCYCLE Programme, International Telecommunication Union (ITU) \& International Solid Waste Association (ISWA), Bonn/Geneva/Rotterdam.

6. Gabaldón C, Izquierdo M, Martínez-Soria V, Marzal P, Penya-roja J-M, Javier Alvarez-Hornos F (2007) Biological nitrate removal from wastewater of a metal-finishing industry. J Hazard Mater 148 (1):485-490. https://doi.org/10.1016/j.jhazmat.2007.02.071

7. González-Domenech CM, Martínez-Checa F, Béjar V, Quesada E (2010) Denitrification as an important taxonomic marker within the genus Halomonas. Syst Appl Microbiol 33 (2):85-93. https://doi.org/10.1016/j.syapm.2009.12.001

8. Hirata A, Nakamura Y, Tsuneda S (2001) Biological nitrogen removal from industrial wastewater discharged from metal recovery processes. Water Sci Technol 44 (2-3):171-179. https://doi.org/10.2166/wst.2001.0767

9. Holmes DE, Dang Y, Smith JA (2019) Nitrogen cycling during wastewater treatment. Adv Appl Microbiol 106:113-192.

10. Işıldar A (2018) 10 - Biotechnologies for metal recovery from electronic waste and printed circuit boards. In: Vegliò F, Birloaga I (eds) Waste Electrical and Electronic Equipment Recycling. Woodhead Publishing, pp 241-269. 10.1016/B978-0-08-102057-9.00010-X

11. Kim KK, Jin L, Yang HC, Lee S-T (2007) Halomonas gomseomensis sp. nov., Halomonas janggokensis sp. nov., Halomonas salaria sp. nov. and Halomonas denitrificans sp. nov., moderately halophilic bacteria isolated from saline water. Int J Syst Evol Microbiol 57 (4):675-681. https://doi.org/10.1099/ijs.0.64767-0

12. Koren DW, Gould WD, Bédard $P$ (2000) Biological removal of ammonia and nitrate from simulated mine and mill effluents. Hydrometallurgy 56 (2):127-144. https://doi.org/10.1016/S0304386X(99)00088-2

13. Kousi P, Remoundaki E, Hatzikioseyian A, Battaglia-Brunet F, Joulian C, Kousteni V, Tsezos M (2011) Metal precipitation in an ethanol-fed, fixed-bed sulphate-reducing bioreactor. J Hazard Mater 189 (3):677-684. https://doi.org/10.1016/j.jhazmat.2011.01.083

14. Kousi P, Remoundaki E, Hatzikioseyian A, Tsezos M (2007) A study of the operating parameters of a sulphate-reducing fixed-bed reactor for the treatment of metal-bearing wastewater. Advanced Materials Research 20-21:230-234. 10.4028/www.scientific.net/AMR.20-21.230

15. Lewis AE (2010) Review of metal sulphide precipitation. Hydrometallurgy 104 (2):222-234. https://doi.org/10.1016/j.hydromet.2010.06.010

16. Magalhães C, Costa J, Teixeira C, Bordalo AA (2007) Impact of trace metals on denitrification in estuarine sediments of the Douro River estuary, Portugal. Mar Chem 107 (3):332-341. https://doi.org/10.1016/j.marchem.2007.02.005

17. Matějů V, Čižinská S, Krejčí J, Janoch T (1992) Biological water denitrification-A review. Enzyme Microb Technol 14 (3):170-183. https://doi.org/10.1016/0141-0229(92)90062-S

18. Mattila K, Zaitsev G, Langwaldt J (2007) Biological removal of nutrients from mine waters (final report). Finnish Forest Research Institute - Rovaniemi Unit, Rovaniemi. 
19. Miao Y, Liao R, Zhang X-X, Liu B, Li Y, Wu B, Li A (2015) Metagenomic insights into salinity effect on diversity and abundance of denitrifying bacteria and genes in an expanded granular sludge bed reactor treating high-nitrate wastewater. Chem Eng J 277:116-123. https://doi.org/10.1016/j.cej.2015.04.125

20. Ochoa-Herrera V, León G, Banihani Q, Field JA, Sierra-Alvarez R (2011) Toxicity of copper(II) ions to microorganisms in biological wastewater treatment systems. Sci Total Environ 412-413:380-385. https://doi.org/10.1016/j.scitotenv.2011.09.072

21. Papirio S, Ylinen A, Zou G, Peltola M, Esposito G, Puhakka JA (2014) Fluidized-bed denitrification for mine waters. Part I: low pH and temperature operation. Biodegradation 25 (3):425-435. https://doi.org/10.1007/s10532-013-9671-0

22. Ramírez JE, Rangel-Mendez JR, Limberger Lopes C, Gomes SD, Buitrón G, Cervantes FJ (2018) Denitrification of metallurgic wastewater: mechanisms of inhibition by $\mathrm{Fe}, \mathrm{Cr}$ and Ni. J Chem Technol Biotechnol 93 (2):440-449. https://doi.org/10.1002/jctb.5374

23. Remoudaki E, Hatzikioseyian A, Kousi P, Tsezos M (2003) The mechanism of metals precipitation by biologically generated alkalinity in biofilm reactors. Water Res 37 (16):3843-3854. https://doi.org/10.1016/S0043-1354(03)00306-3

24. Remoundaki E, Hatzikioseyian A, Kaltsa F, Tsezos M The role of metal-organic complexes in the treatment of chromium containing effluents in biological reactors. In: Tsezos M, Remoudaki $E$, Hatzikioseyian A (eds) Biohydrometallurgy: a sustainable technology in evolution, Proceedings of the International Biohydrometallurgy Symposium IBS 2003, Athens, Greece, 2003. National Technical University of Athens (NTUA), pp 711-718.

25. Remoundaki E, Hatzikioseyian A, Tsezos M (2007) A systematic study of chromium solubility in the presence of organic matter: Consequences for the treatment of chromium-containing wastewater. $J$ Chem Technol Biotechnol 82 (9):802-808. https://doi.org/10.1002/jctb.1742

26. Sakadevan K, Zheng H, Bavor HJ (1999) Impact of heavy metals on denitrification in surface wetland sediments receiving wastewater. Water Sci Technol 40 (3):349-355. https://doi.org/10.1016/S02731223(99)00471-0

27. Tavares P, Pereira AS, Moura JJG, Moura I (2006) Metalloenzymes of the denitrification pathway. J Inorg Biochem 100 (12):2087-2100. https://doi.org/10.1016/j.jinorgbio.2006.09.003

28. Tsezos M, Remoundaki E, Hatzikioseyian A (2007) Bioprocessing - Principles and applications for metal immobilization from waste-water streams. In: Cox M, Negre P, Yurramendi L (eds) A Guide Book on the Treatment of Effluents from the Mining/Metallurgy, Paper, Plating and Textile Industries. INASMET-Tecnalia, Spain.

29. Tuncuk A, Stazi V, Akcil A, Yazici EY, Deveci H (2012) Aqueous metal recovery techniques from escrap: Hydrometallurgy in recycling. Miner Eng 25 (1):28-37. https://doi.org/10.1016/j.mineng.2011.09.019

30. Tunsu C, Retegan T (2016) Chapter 6 - Hydrometallurgical Processes for the Recovery of Metals from WEEE. In: Chagnes A, Cote G, Ekberg C, Nilsson M, Retegan T (eds) WEEE Recycling. Elsevier, pp 139- 
175. https://doi.org/10.1016/B978-0-12-803363-0.00006-7

31. Woolfenden HC, Gates AJ, Bocking C, Blyth MG, Richardson DJ, Moulton V (2013) Modeling the effect of copper availability on bacterial denitrification. MicrobiologyOpen 2 (5):756-765. https://doi.org/10.1002/mbo3.111

32. You Q-G, Wang J-H, Qi G-X, Zhou Y-M, Guo Z-W, Shen Y, Gao X (2020) Anammox and partial denitrification coupling: a review. RSC Advances 10 (21):12554-12572.

33. Zhao S, Su X, Wang Y, Yang X, Bi M, He Q, Chen Y (2020) Copper oxide nanoparticles inhibited denitrifying enzymes and electron transport system activities to influence soil denitrification and $\mathrm{N}_{2} \mathrm{O}$ emission. Chemosphere 245:125394. https://doi.org/10.1016/j.chemosphere.2019.125394

34. Zou G, Papirio S, van Hullebusch ED, Puhakka JA (2015) Fluidized-bed denitrification of mining water tolerates high nickel concentrations. Bioresour Technol 179:284-290. https://doi.org/10.1016/j.biortech.2014.12.044

35. Zou G, Papirio S, Ylinen A, Di Capua F, Lakaniemi AM, Puhakka JA (2014) Fluidized-bed denitrification for mine waters. Part II: effects of $\mathrm{Ni}$ and Co. Biodegradation 25 (3):417-423. https://doi.org/10.1007/s10532-013-9670-1

\section{Figures}




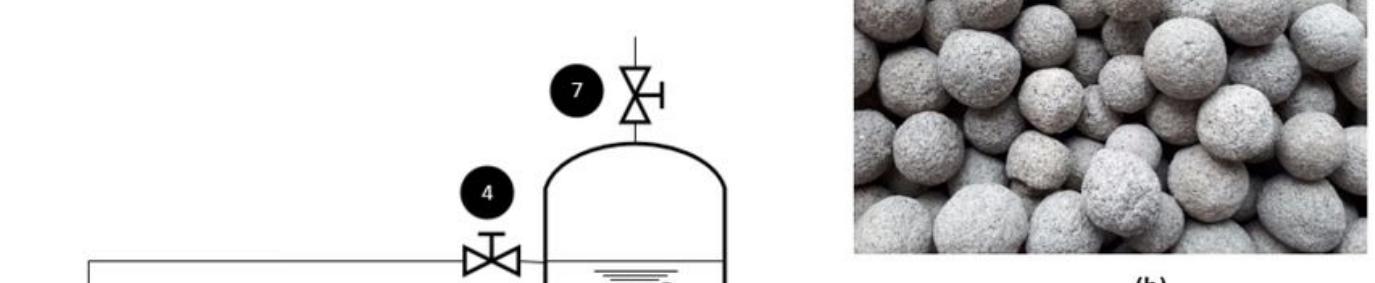

(b)

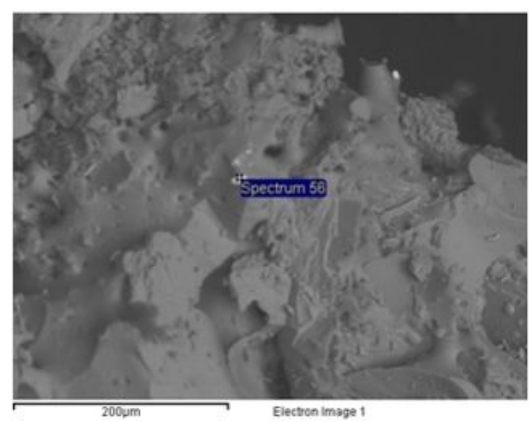

(d)

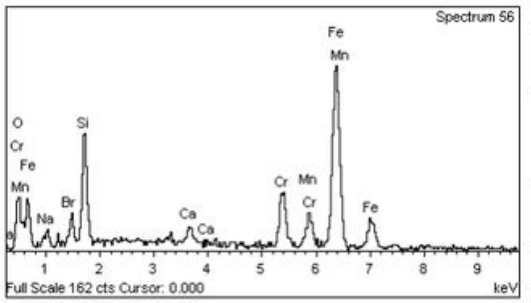

(f)

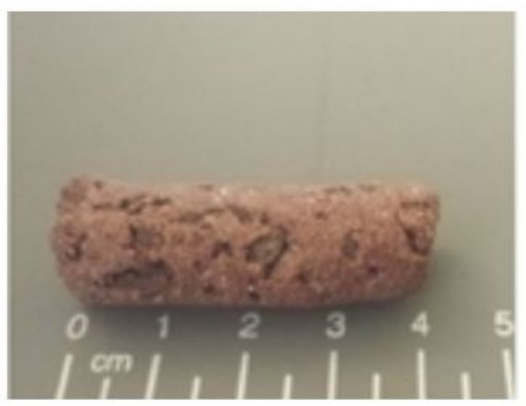

(c)

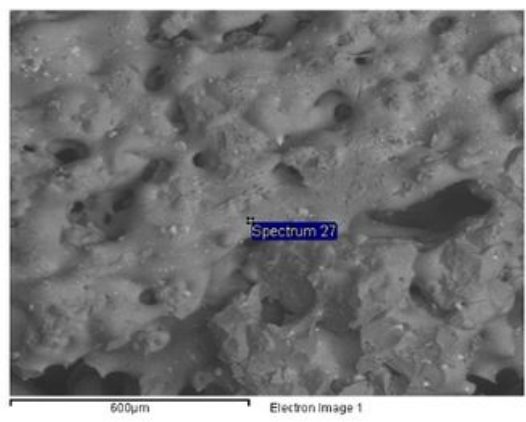

(e)

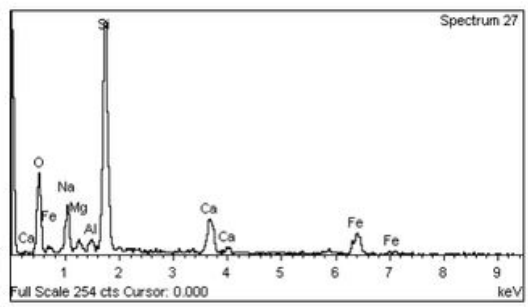

(g)

\section{Figure 1}

(a) Layout of the denitrification unit: (1) column feed from the completely stirred tank reactor (CSTR), (2) peristaltic pump, (3) packed bed bioreactor, (4) reactor effluent stream, $(5,6)$ sampling ports, $(7)$ gas vent, (b) picture of Biohome Supergravel packing material and (c) picture of Biohome Ultimate packing material, with their corresponding (d) and (e) SEM images, and their (f) and (g) EDS spectra for selected spots on their surface.
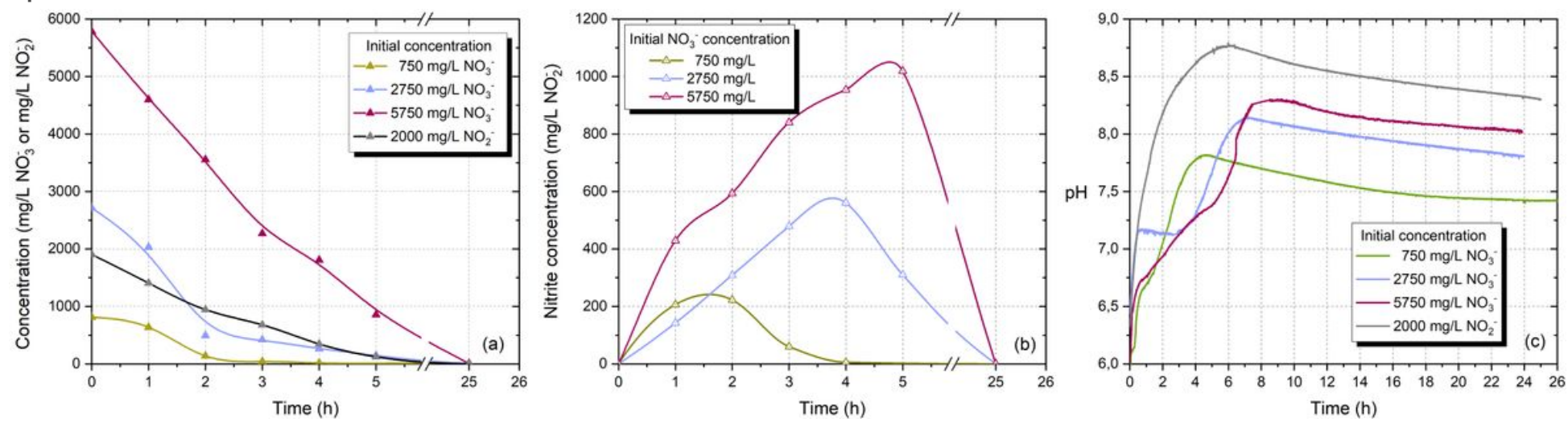

Figure 2 
Concentration profiles of (a) nitrate and nitrite, (b) produced nitrite and, (c) profiles of $\mathrm{pH}$ during denitrification process.
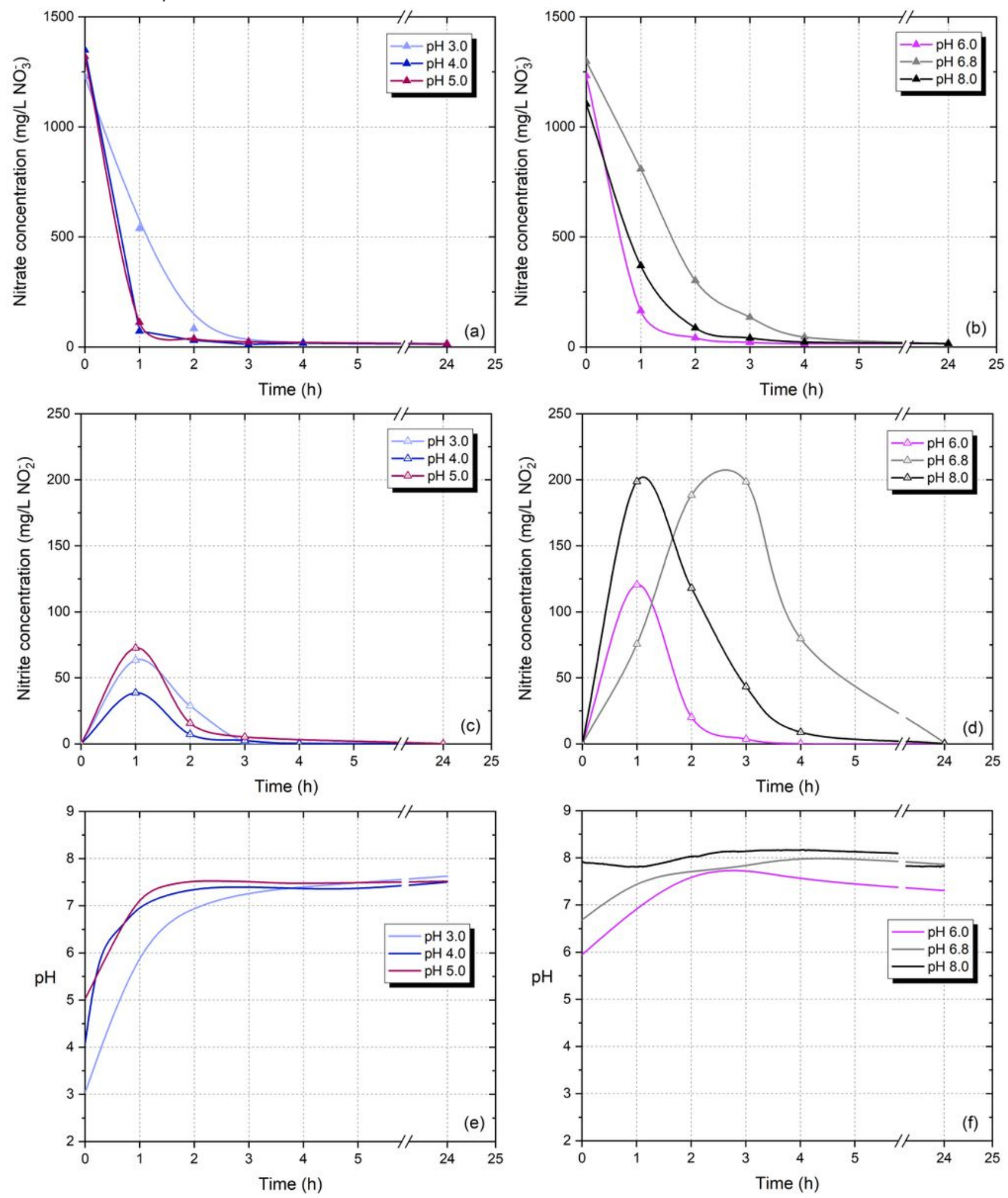

Figure 3

Effect of initial pH on the denitrification process: (a), (b) concentration profiles of nitrate, (c), (d) concentration profiles of nitrite, (e), (f) $\mathrm{pH}$ profiles for initial $\mathrm{pH} \mathrm{3,4,5}$ and 6, 6.8 and 8, respectively. 

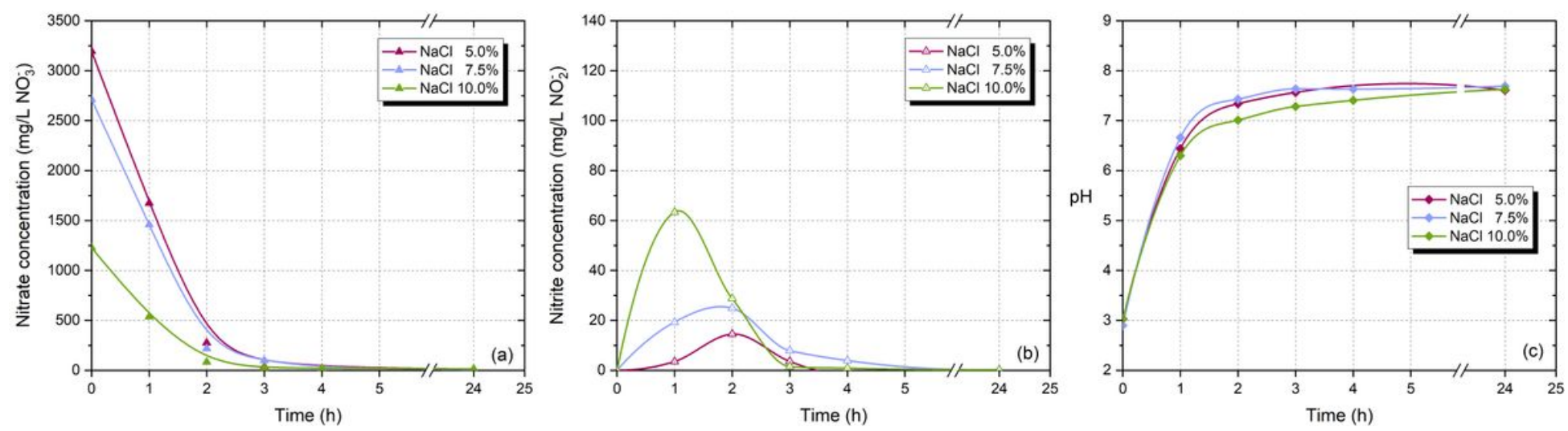

Figure 4

The effect of salinity on (a) the concentration of nitrate, (b) the concentration of nitrite and, (c) pH profiles for salinity levels $5 \%, 7.5 \%$ and $10 \%$ in the wastewater. 

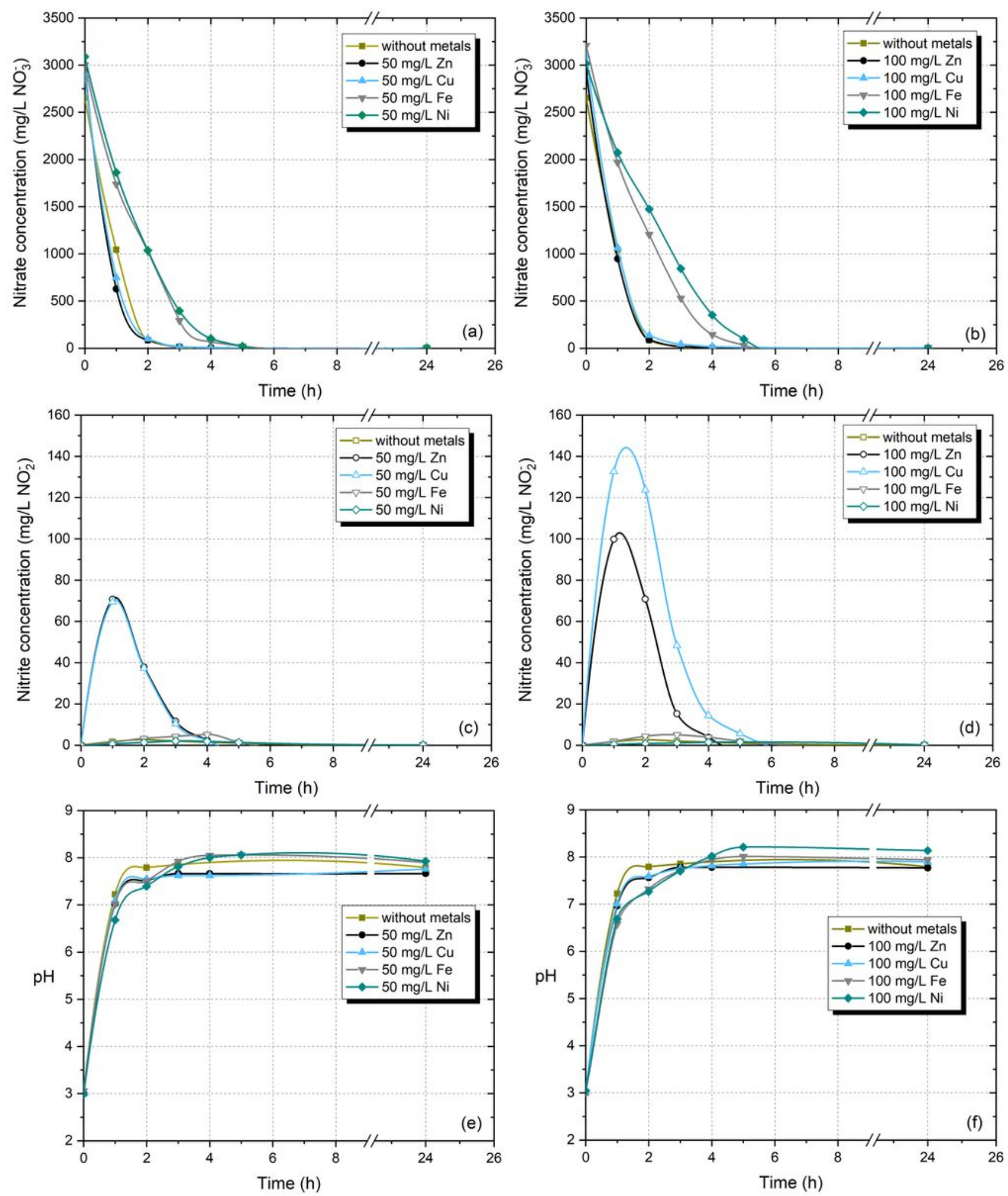

\section{Figure 5}

The effect of $\mathrm{Zn}, \mathrm{Cu}, \mathrm{Fe}$ and $\mathrm{Ni}$ on (a), (b) nitrate reduction, (c), (d) nitrite production and, (e), (f) pH profiles at $50 \mathrm{mg} / \mathrm{L}$ and $100 \mathrm{mg} / \mathrm{L} \mathrm{Zn}, \mathrm{Cu}, \mathrm{Fe}, \mathrm{Ni}$ respectively. 

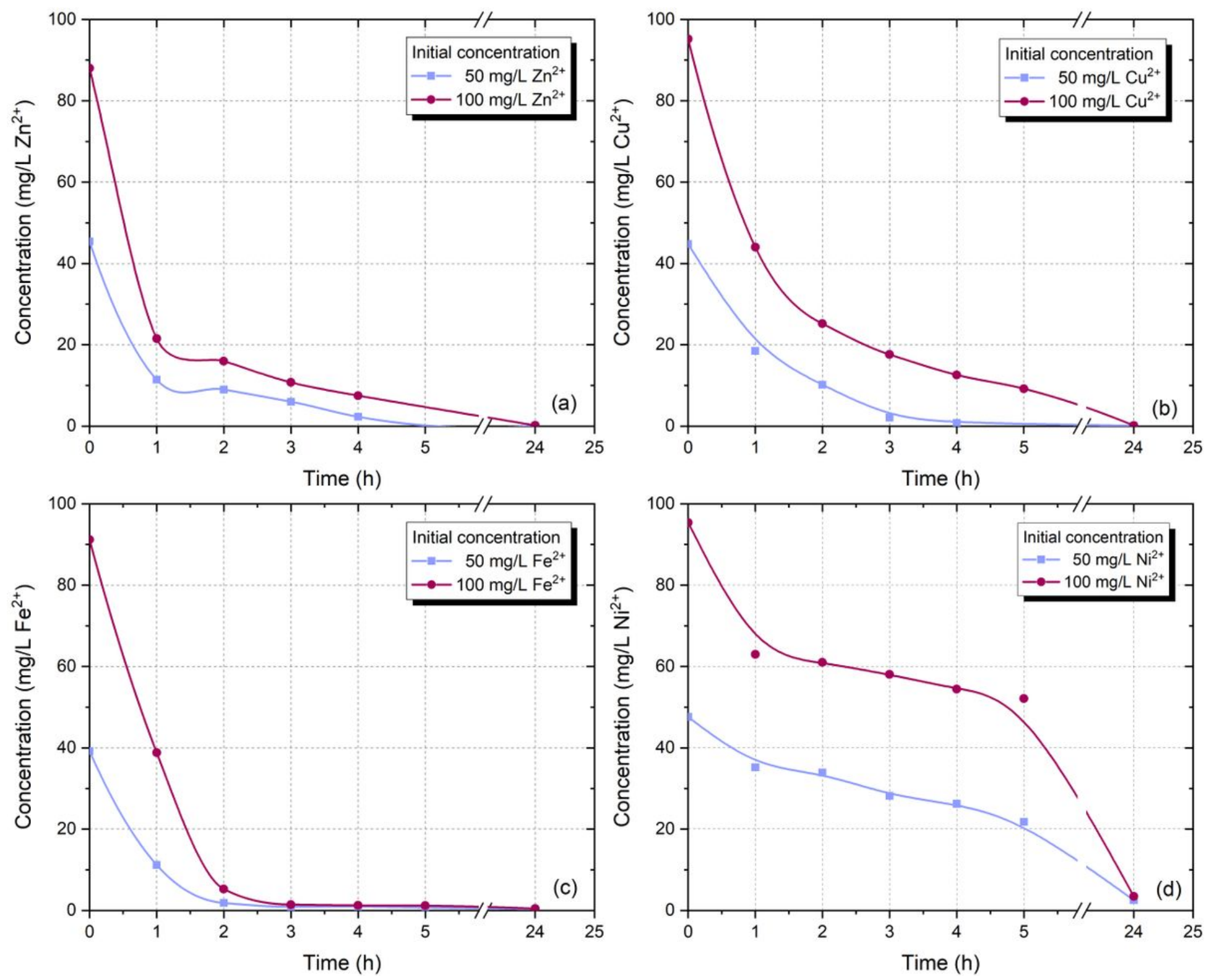

Figure 6

Concentration profiles of $\mathrm{Zn}, \mathrm{Cu}, \mathrm{Fe}$ and $\mathrm{Ni}$ during denitrification at $50 \mathrm{mg} / \mathrm{L}$ and $100 \mathrm{mg} / \mathrm{L}$, respectively.

\section{Supplementary Files}

This is a list of supplementary files associated with this preprint. Click to download.

- Supplementarymaterial.docx 